\title{
Seasonal dynamics and annual production of Cystoseira crinita (Fucales: Ochrophyta)-dominated assemblages from the northwestern Mediterranean
}

\author{
MARTA SALES ${ }^{1}$ and ENRIC BALLESTEROS ${ }^{2}$ \\ ${ }^{1}$ Estació d'Investigació Jaume Ferrer, IEO-Centre Oceanogràfic de les Balears, La Mola, P.O. Box 502, 07701 Maó, \\ Spain. E-mail: marta.sales@ba.ieo.es \\ ${ }^{2}$ Centre d’Estudis Avançats de Blanes, CSIC, Acc. Cala St. Francesc 14, 17300 Blanes, Spain.
}

\begin{abstract}
SUMMARY: Algae of the genus Cystoseira are the main engineering species on Mediterranean shallow rocky bottoms. Cystoseira crinita is an endemic species which grows in shallow and rather sheltered environments throughout the entire Mediterranean Sea. In order to investigate its role in structuring benthic assemblages and as a primary producer, three localities were sampled every two months during one year in Menorca (Balearic Islands). The total biomass of Cystoseira crinita-dominated assemblages showed a seasonal pattern mainly due to temporal changes in the biomass of the dominant alga. The assemblages also showed seasonality in their species richness (number of species per sample). Both total biomass and species richness peaked in summer, and their lowest values were recorded in winter. Despite these temporal patterns, $C$. crinita-dominated assemblages from Menorca showed reduced seasonality compared to C. crinita-dominated assemblages in other areas in the western Mediterranean, as C. crinita specimens kept their branches throughout the entire year. Total annual production of Cystoseira crinita branches and cauloids was around $1230 \mathrm{~g} \mathrm{dwt} \mathrm{m}^{-2}$, which is higher than that of other Cystoseira species living in sheltered areas but much lower than that of Cystoseira species growing on exposed shores. Production was highly seasonal, and was highest in spring and null in winter and late summer.
\end{abstract}

Keywords: annual production, assemblage structure, biomass, Cystoseira crinita, seasonality, species richness.

RESUMEN: DiNÁMICA ESTACIONAL Y PRODUCCIÓN ANUAL DE LAS COMUNIDADES DOMINADAS POR CYSTOSEIRA CRINITA (FUCAles: Ochrophyta) DEl MediterráneO nOROCCIDENTAl. - Las algas del género Cystoseira son las principales especies estructuradoras de hábitat en los fondos rocosos infralitorales mediterráneos. Cystoseira crinita es una especie endémica que crece en fondos someros y poco expuestos al oleaje en todo el Mediterráneo. Con la intención de estudiar su papel estructurador en las comunidades bentónicas y como productor primario, se muestrearon tres localidades, cada dos meses durante un año, en Menorca, Islas Baleares. Las comunidades dominadas por Cystoseira crinita mostraron un ciclo anual bien establecido en su biomasa total, debido principalmente a los cambios temporales de biomasa del alga Cystoseira crinita. Las comunidades también mostraron cambios en su riqueza específica (número de especies por muestra). Tanto la biomasa total como la riqueza específica fueron máximas en verano, mientras sus valores mínimos se obtuvieron en invierno. A pesar de estos patrones temporales, las comunidades de C. crinita estudiadas mostraron una estacionalidad menor que la encontrada en otras zonas, puesto que $C$. crinita mantuvo sus rámulos durante todo el año. La producción total anual de los rámulos y cauloides de Cystoseira crinita fue de $1230 \mathrm{~g}$ peso seco $\mathrm{m}^{-2}$, más elevada que la de otras especies de Cystoseira de modo calmo, pero muy inferior a las medidas obtenidas en especies de Cystoseira que crecen en lugares expuestos. La producción fue marcadamente estacional, con máximos en primavera y con valores nulos en invierno y final de verano.

Palabras clave: biomasa, Cystoseira crinita, estacionalidad, estructura, producción anual, riqueza específica.

\section{INTRODUCTION}

Algae in the orders Laminariales and Fucales are the main engineering species in sublittoral rocky bottoms of all temperate areas in the world (Ribera et al.
1992, Steneck et al. 2002). They are very important primary producers in coastal areas (Mann 1973) where they dominate structurally complex and diverse assemblages (Duggins 1980, Reed and Foster 1984, Graham 2004). Moreover, assemblages dominated by Fucales 
serve as nursery habitats for some littoral fishes (Aburto-Oropeza et al. 2007, Cheminee et al. 2010). The majority of shallow rocky temperate coasts are occupied by Laminariales, commonly known as kelps (Dayton 1985, Steneck et al. 2002), while in the Mediterranean Sea these areas are occupied by algae of the genus Cystoseira (Fucales) (Giaccone 1973, Ballesteros 1992). The particular characteristics of the Mediterranean Sea compared to open temperate oceans, i.e. extremely reduced tides, oligotrophy, relatively high salinity and a high mean summer temperature (Ros et al. 1985), probably prevent the growth of kelp beds. The genus Cystoseira is present in the northern Atlantic Ocean and in the Mediterranean Sea (Draisma et al. 2010), and it is especially diverse in the Mediterranean (ca. 50 species). Different species occupy different habitats depending on depth, degree of exposure to wave action, and other environmental factors (Giaccone 1971, Ballesteros 1992, Sales and Ballesteros 2009). Most of the species of the genus Cystoseira are very sensitive to pollution and to other anthropogenic pressures, and they have decreased considerably during the last decades in many areas of the Mediterranean (Cormaci and Furnari 1999, Thibaut et al. 2005, Serio et al. 2006, Mangialajo et al. 2008). All the species of the genus Cystoseira except $C$. compressa are included in Annex II of the Barcelona Convention. The seasonal dynamics and annual production of Cystoseira-dominated assemblages have been studied by several authors (e.g. Ballesteros 1988a, 1989, 1990a,b, Pizzuto 1999), and have been found to show marked seasonality in the abundance of the dominant species and overall species composition.

Cystoseira crinita is an endemic Mediterranean species that is distributed throughout the entire Mediterranean (Ribera et al. 1992, Sales et al. 2012). It usually grows in the upper infralittoral zone on both low and intermediately exposed gently sloping rocky bottoms that are often subjected to a high degree of sedimentation (Sales and Ballesteros 2009, 2010). Cystoseira crinita dominates very structured assemblages that were originally described as an algal association by Molinier (1960). Historically, shallow, sheltered areas have been preferred zones for human settlements, which has profoundly altered these areas. This, together with the relatively high sensitivity of $C$. crinita to human pressures (Sales et al. 2011), makes this species especially vulnerable. Despite the importance of $C$. crinita in structuring assemblages, the seasonal dynamics and productivity of C. crinita-dominated assemblages are poorly known. The seasonality of $C$. crinita-dominated assemblages has only been studied at two sites: one in Sicily, Italy (Pizzuto 1999), and one in Catalonia, Spain (Ballesteros 1992). Almost nothing is known about its productivity. In Menorca (Balearic Islands), $C$. crinita is quite abundant in most of the coves and bays from the northern coast of the island, where it dominates complex algal assemblages (Sales and Ballesteros 2009). In terms of species composition and structure, these assemblages are representative of the $C$. crinita-dominated assemblages from the northwestern Mediterranean (Sales et al. 2012).

Considering the important role that Cystoseira crinita plays in structuring littoral assemblages (Boudouresque 1972, Ballesteros 1992, Pizzuto 1999, Sales et al. 2012) and its potential role as a primary producer, it is of interest to study (1) the seasonal variation in species composition and structure of the $C$. crinitadominated assemblages, and (2) the annual production of these assemblages.

\section{MATERIALS AND METHODS}

\section{Study sites}

Three study sites were selected on the northern coast of Menorca (Balearic Islands), where assemblages dominated by Cystoseira crinita are frequent in shallow (0-1 m depth), rather sheltered areas (Sales and Ballesteros 2009). The selected sites were Cala Barril ( $\left.40^{\circ} 03^{\prime} \mathrm{N}, 04^{\circ} 01^{\prime} \mathrm{E}\right)$, Cala Pregonda $\left(40^{\circ} 03^{\prime} \mathrm{N}\right.$, $\left.04^{\circ} 02^{\prime} \mathrm{E}\right)$, and Macar de Tirant $\left(40^{\circ} 03^{\prime} \mathrm{N}, 04^{\circ} 05^{\prime} \mathrm{E}\right)$ (Fig. 1), which are north-oriented coves that are fairly sheltered and have gently sloping rocky bottoms in the first meter depth.

\section{Environmental characterization}

The temperature was measured monthly at each location during the study period (November 2006 November 2007). Surface seawater samples (3 replicates) were collected monthly from each study location in order to determine the concentration of inorganic dissolved nutrients (phosphates, nitrates and nitrites). Analytical procedures followed Grasshoff et al. (1983) using an Alliance Evolution II Autoanalyzer. Two-way analysis of variance (ANOVA) was used to examine differences in inorganic nutrient concentration in seawater among study locations and dates (sampling times). Data were previously log $(x+1)$-transformed in order to achieve homogeneity of variances. Irradiance values for the study area were obtained from the $\mathrm{Na}$ tional Meteorological Agency (AEMET).

\section{Seasonal dynamics of assemblage structure}

The species composition and species abundances of Cystoseira crinita-dominated assemblages were monitored from November 2006 to November 2007 at the three study locations. Three samples (replicates) were randomly collected every two months from each location, avoiding re-sampling. Each sample consisted of a square surface of $400 \mathrm{~cm}^{2}$ from which the whole community (except the encrusting algae) was removed with a hammer and chisel (Boudouresque 1971). This sampling area is equal to the minimum sampling area recommended for sampling Mediterranean infralittoral assemblages (Coppejans 1980, Ballesteros 1992). 


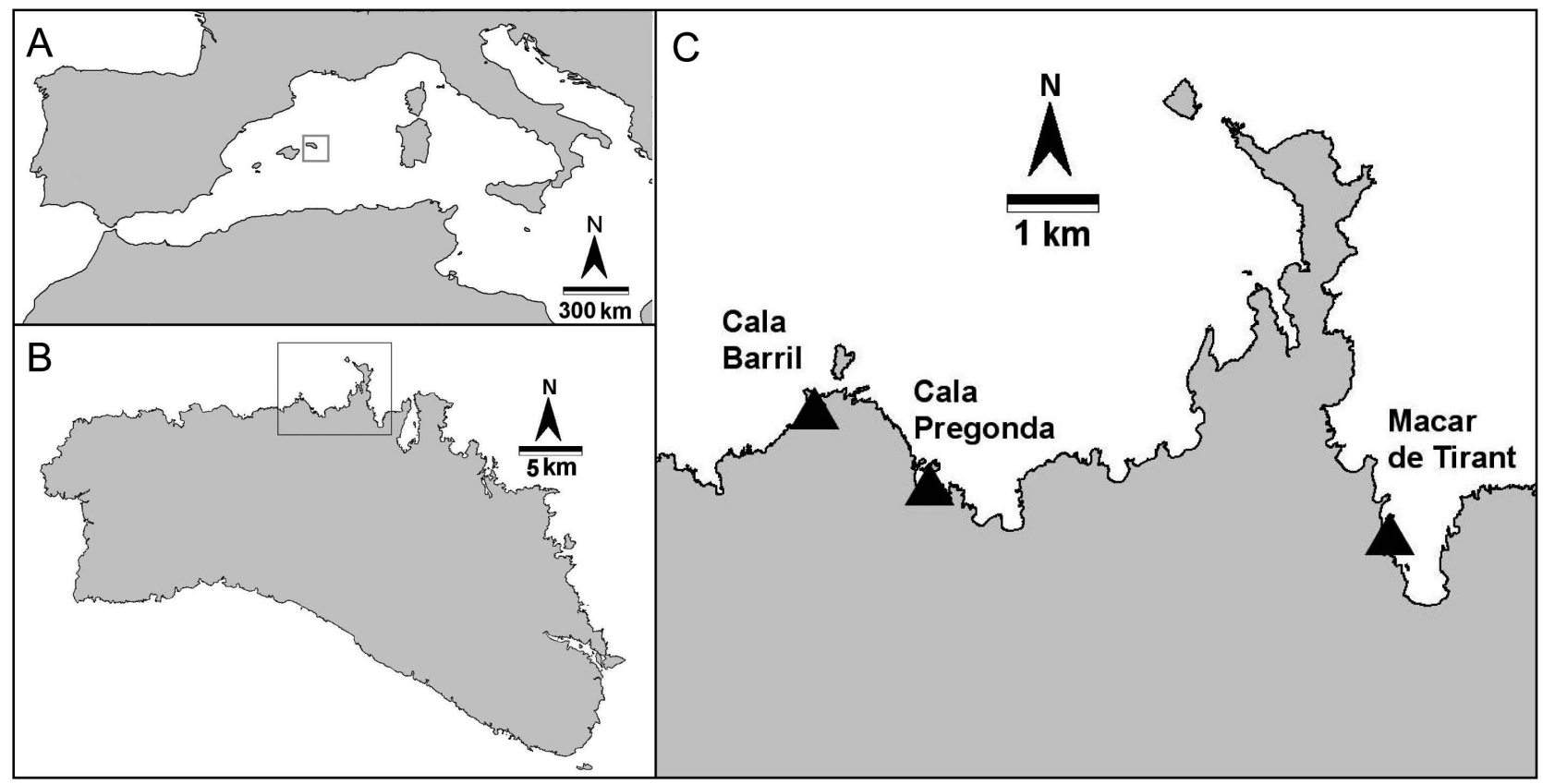

FIG. 1. - Map of the study area showing the locations of the study sites.

In the laboratory, the samples were sorted, and algal and sessile invertebrate species were identified and quantified as horizontal coverage in $\mathrm{cm}^{2}$ and biomass ( $\mathrm{g} \mathrm{dwt}$ ) following procedures described in Ballesteros (1986). Two biological data matrices were obtained: one with species abundances expressed as coverage in $\mathrm{cm}^{2}$ (cover database) and one with species abundances expressed as biomass in g dwt (biomass database).

Non-metric multidimensional scaling (MDS) ordination (Kruskal and Wish 1978) was used to visualize patterns of community similarities among study locations and sampling times. Centroids (Anderson et al. 2008) were obtained and represented for each location and sampling time (each one was determined from three replicates). The ordination was performed on the cover database, which was previously transformed to fourth roots in order to reduce the contribution of the most abundant species, especially the dominant Cystoseira crinita. The Bray-Curtis similarity index (Bray and Curtis 1957) was used to construct the similarity matrix. A PERMANOVA (Anderson 2001) was also applied to the cover database to test the null hypothesis of no differences among locations and sampling times. A Relate Test against a cyclicity model matrix (Clarke and Gorley 2006) was used to test the changes in community structure according to a seasonal pattern. Two-way ANOVA was used to test for differences in total biomass (taking into account all the organisms in the assemblage), $C$. crinita biomass, and the biomass of accompanying species among study sites and sampling dates. Two-way ANOVA was also used to test for differences in species richness (number of species per sample) and Shannon Diversity indices among study sites and sampling dates (using cover data). All of these variables showed homogeneously distributed variances and so it was not necessary to transform them in any way.

\section{Annual production}

The branch and cauloid production of Cystoseira crinita as well as the daily turnover ratio (r) were calculated for each location and time interval (time between each two consecutive sampling times). Branches are not perennial, and so the production of C. crinita was calculated by means of its annual biomass cycle using the biomass database previously mentioned. Differences in biomass were calculated for each time interval and interpreted as close estimates of production. However, C. crinita cauloids are perennial, and so their production was estimated by randomly choosing and tagging 100 cauloids within the assemblages at Cala Pregonda. Their lengths were monitored every four months during one year and the mean cauloid growth was calculated for each time interval. The relationship between the cauloid length and cauloid biomass was calculated from $100 \mathrm{C}$. crinita cauloids that were collected, measured and dried to a constant weight at $100^{\circ} \mathrm{C}$ during 48 hours. Growth values were converted to biomass values. The initial cauloid biomass per $\mathrm{m}^{2}$ was calculated from data on the density and size structure of $C$. crinita assemblages obtained from measures taken in ten $20 \times 20 \mathrm{~cm}$ quadrats randomly placed over the $C$. crinita assemblages at Cala Pregonda. To calculate the daily turnover ratio (r) of both the branches and cauloids, the following formula (Ballesteros 1992) was used:

$$
r=\ln \left(\frac{P}{B_{1}}+1\right) \Delta t^{-1}
$$



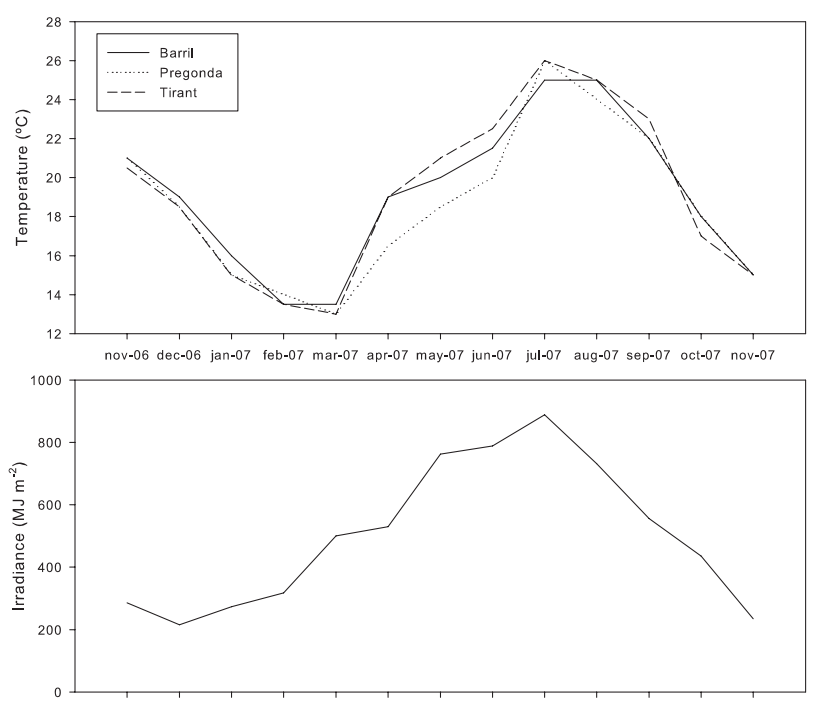

nov-06 dec-06 jan-07 feb-07 mar-07 apr-07 may-07 jun-07 jul-07 aug-07 sep-07 oct-07 nov-07

FIG. 2. - Seasonal variation of environmental parameters. Upper panel: temperature values measured monthly in situ at the three study sites during the entire study period. Lower panel: Irradiance values from the study area and for the whole study period obtained from AEMET (Spanish Meteorological Agency).

where $P$ is the production attained during a given time interval (in $\mathrm{g} \mathrm{dwt}$ ), $B_{1}$ is the initial biomass (in $\mathrm{g} \mathrm{dwt}$ ), and $\Delta t$ is the time length of the given interval (in days).

\section{RESULTS}

\section{Environmental characterization}

Seawater temperature varied between $13^{\circ} \mathrm{C}$ in March 2007 and $26^{\circ} \mathrm{C}$ in July 2007 with low variations among sampling locations (Fig. 2). The minimum surface irradiance was recorded in December 2006, with $215 \mathrm{MJ} \mathrm{m}^{-2}$, and the maximum in July 2007, with $888 \mathrm{MJ} \mathrm{m}^{-2}$ (Fig. 2). Nutrient concentrations were very low and did not vary significantly among locations and dates, except for the nitrate concentration, which was significantly higher in Cala Pregonda than in the other two locations studied (Table 1). The mean $\mathrm{NO}_{3}$ concentration $( \pm \mathrm{SE})$ in Cala Pregonda was $0.132 \mu \mathrm{M}( \pm 0.045)$, while in Cala Barril it was 0.023 $\mu \mathrm{M}( \pm 0.005)$ and in Macar de Tirant it was $0.036 \mu \mathrm{M}$ $( \pm 0.006)$. The mean $\mathrm{PO}_{4}$ concentration values $( \pm \mathrm{SE})$ were $0.061 \mu \mathrm{M}( \pm 0.004)$ for Cala Barril, $0.081 \mu \mathrm{M}$ $( \pm 0.010)$ for Cala Pregonda, and $0.099 \mu \mathrm{M}( \pm 0.026)$ for Macar de Tirant. Finally, mean $\mathrm{NO}_{2}$ concentrations $( \pm \mathrm{SE})$ were $0.164 \mu \mathrm{M}( \pm 0.015)$ in Cala Barril, $0.246 \mu \mathrm{M}( \pm 0.182)$ in Cala Pregonda, and $0.210 \mu \mathrm{M}$ $( \pm 0.025)$ in Cala Tirant.

\section{Seasonal dynamics of assemblage structure}

A total of 79 species were recorded from the samples, consisting of 2 cyanobacteria, 71 macroalgae (Chlorophyta, Ochrophyta, Rhodophyta) and 6 sessile invertebrates. Quantified species lists are shown in
TABLE 1. - Results of the two-way ANOVA for comparing nutrient concentrations among study locations and sampling dates. Bold: significant $\mathrm{P}$ values.

\begin{tabular}{lcrccc}
\hline Effect & SS & d.f. & MS & F & $P$ \\
\hline $\mathrm{PO}_{4}$ & & & & & \\
$\quad$ Location & 0.028 & 2 & 0.014 & 1.386 & 0.256 \\
$\quad$ Date & 0.108 & 12 & 0.009 & 0.897 & 0.554 \\
$\quad$ Location $\times$ Date & 0.275 & 24 & 0.011 & 1.144 & 0.320 \\
$\quad$ Error & 0.782 & 78 & 0.010 & & \\
& & & & & \\
$\mathrm{NO}_{3}$ & & & & & \\
$\quad$ Location & 0.276 & 2 & 0.138 & 5.189 & $\mathbf{0 . 0 0 8}$ \\
$\quad$ Date & 0.429 & 12 & 0.036 & 1.348 & 0.210 \\
$\quad$ Location $\times$ Date & 0.543 & 24 & 0.023 & 0.852 & 0.661 \\
$\quad$ Error & 2.071 & 78 & 0.023 & & \\
$\quad$ & & & & & \\
$\mathrm{NO}_{2}$ & & & & & \\
$\quad$ Location & 0.13 & 2 & 0.065 & 0.150 & 0.861 \\
$\quad$ Date & 4.47 & 12 & 0.372 & 0.859 & 0.591 \\
$\quad$ Location×Date & 12.01 & 24 & 0.500 & 1.154 & 0.310 \\
$\quad$ Error & 33.807 & 78 & 0.433 & & \\
\hline
\end{tabular}

${ }^{a}$ Tukey test: Pregonda $>$ Barril and Tirant $(P<0.05)$

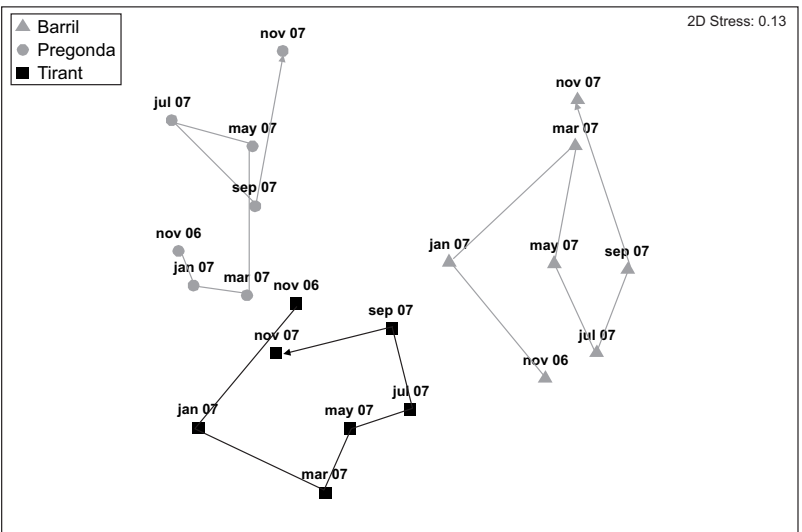

FIG. 3. - MDS ordination of the samples showing centroids for each study site and sampling time $(n=3)$. Seasonal trajectories are indicated by arrows for each study site.

Annex 1 . The canopy stratum was always dominated by Cystoseira crinita, sometimes accompanied by a few individuals of Cystoseira spinosa var. tenuior. The most characteristic accompanying species were the coralline algae Haliptilon virgatum and Jania rubens, growing either as epiphytes of $C$. crinita or in the understory of the assemblage. Other epiphytes that were frequently found growing over $C$. crinita were the brown algae Dictyota mediterranea and Sphacelaria cirrosa, the red algae Herposiphonia secunda and Dipterosiphonia rigens, and the cyanobacteriae Calothrix confervicola and Symploca hydnoides (Annex 1). In the understory, the most frequent species were Corallina elongata and the green algae Cladophora prolifera and Dasycladus vermicularis. The assemblage was not observed to change greatly during the year. Cystoseira crinita kept its branches throughout the entire year; however, growth of new branches was observed during spring. Only a few accompanying species showed a clear maximum abundance in summer and autumn (e.g. Dictyota mediterranea and Symploca hydnoides), 
TABLE 2. - Results of PERMANOVA analysis of community structure (cover database) for the factors Location and Date (fixed factors). Bold: significant $P$ values; $* P<0.05$.

\begin{tabular}{lcccc}
\hline Source of variation & df & MS & F & $P$ \\
\hline Location & 2 & 9012.10 & 15.5130 & $\mathbf{0 . 0 0 0 1}$ \\
Date & 6 & 1987.90 & 3.4219 & $\mathbf{0 . 0 0 0 1}$ \\
Location $\times$ Date & 12 & 890.47 & 1.5328 & $\mathbf{0 . 0 0 1 4}$ \\
Residual & 42 & 580.93 & & \\
Total & 62 & & & \\
\hline
\end{tabular}

Significant a posteriori comparisons for factor Date in each Location: Cala Barril: nov06-nov07 (*); Cala Pregonda: Jan07-Nov07 (*), Sep07-Nov07 (*); Macar de Tirant: Nov06-Mar07 (*), Jan07Mar07 (*), Jan07-Jul07 (*), Jan07-Sep07 (*).

TABLE 3. - Results of two-way ANOVA tests for determining differences in total biomass, biomass of $C$. crinita, biomass of companion species, number of species per sample, and Shannon diversity, among locations and sampling times. Bold: significant $P$ values; $* P<0.05$, ** $P<0.01, * * * P<0.001$. Abbreviations: BM, biomass; $\mathrm{B}$, Cala Barril; P, Cala Pregonda; T, Macar de Tirant.

\begin{tabular}{lcccc}
\hline Source of variation & df & MS & F & $P$ \\
\hline Total BM & & & & \\
$\quad$ Location & 2 & 477 & 1.129 & 0.333 \\
Time & 6 & 2063 & 4.879 & $\mathbf{0 . 0 0 1}$ \\
Location $\times$ Time & 12 & 565 & 1.336 & 0.235 \\
Error & 42 & 423 & &
\end{tabular}

aTukey test: Jan07 < Jul07 (***), Mar07 < Ju107 (**), Jul07 > Nov07 (**)

\begin{tabular}{|c|c|c|c|c|}
\hline \multicolumn{5}{|l|}{1 of $C$. crinita } \\
\hline Location & 2 & 1634 & 5.639 & $0.007^{b}$ \\
\hline Time & 6 & 1859 & 6.414 & $0.000^{c}$ \\
\hline Location×Time & 12 & 521 & 1.799 & 0.080 \\
\hline Error & 42 & 290 & & \\
\hline bTukey test: $\mathrm{B}>\mathrm{T}$ & & & & \\
\hline $\begin{array}{l}\text { 'Tukey test: Jan07 } \\
(* *)\end{array}$ & $7(*$ & Mar07 & $7(* * *)$ & $>$ Nov07 \\
\hline $\mathrm{BM}$ companion $\mathrm{sp}$ & & & & \\
\hline Location & 2 & 354.4 & 4.791 & $0.013^{d}$ \\
\hline Time & 6 & 18.8 & 0.254 & 0.955 \\
\hline Location×Time & 12 & 75.9 & 1.025 & 0.444 \\
\hline Error & 42 & 74.0 & & \\
\hline${ }^{\mathrm{d}}$ Tukey test: $\mathrm{B}<\mathrm{T}$ & & & & \\
\hline No. sps. per sampl & & & & \\
\hline Location & 2 & 19.00 & 1.474 & 0.241 \\
\hline Time & 6 & 58.62 & 4.548 & $0.001^{e}$ \\
\hline Location×Time & 12 & 20.56 & 1.595 & 0.130 \\
\hline Error & 42 & 12.89 & & \\
\hline $\begin{array}{l}\text { eTukey test: Nov06 } \\
\text { Nov07 (**) }\end{array}$ & $\mathrm{p}^{2}$ & \ay07 & v07 (*) & $7>$ \\
\hline Shannon diversity & & & & \\
\hline Location & 2 & 0.771 & 11.49 & $0.000^{f}$ \\
\hline Time & 6 & 0.057 & 0.85 & 0.538 \\
\hline Location $\times$ Time & 12 & 0.075 & 1.12 & 0.369 \\
\hline Error & 42 & 0.067 & & \\
\hline
\end{tabular}

while most of the other species showed erratic changes in abundance over the year (see Annex I).

The MDS ordination (Fig. 3) separated the assemblages primarily by location and secondarily by sam-

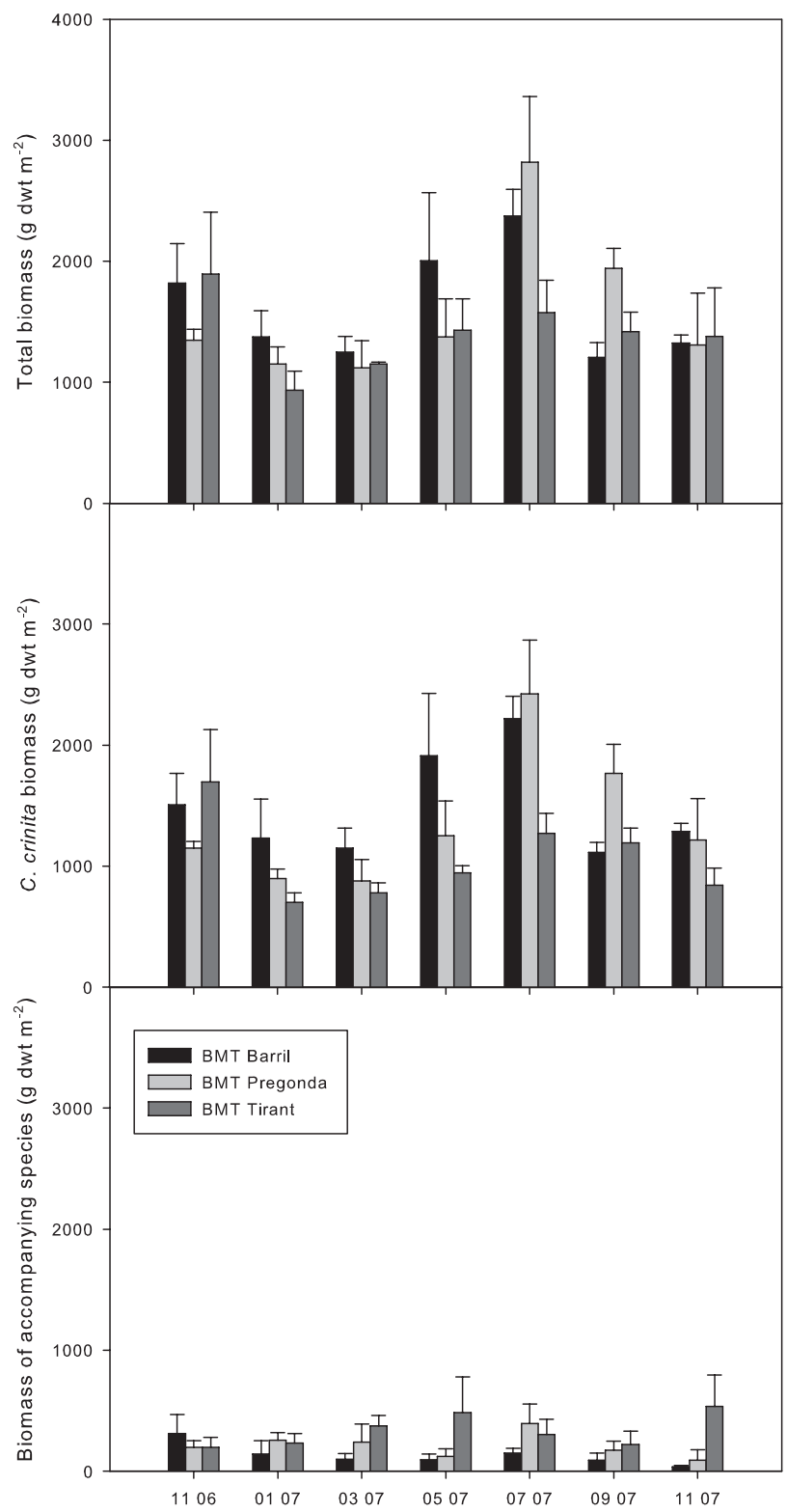

FIG. 4. - Mean biomass values (+ 1SE) of different components of the studied assemblages for each sampling time and location.

pling time. However, both location and sampling time were significant factors in determining the composition and structure of $C$. crinita assemblages (PERMANOVA, $P=0.0001$, see Table 2). The seasonal trajectory, drawn for each location in Figure 3, indicated cyclicity only in the location Macar de Tirant (significant Relate Test: Rho=0.387, $P=0.0001)$. The trajectories followed by the assemblages from Cala Pregonda and Cala Barril showed erratic changes tending to an upper position in the MDS from November 2006 to November 2007 (no significant Relate Tests; Cala Pregonda: Rho $=0.186$, $P=0.097$; Cala Barril: Rho $=0.112, P=0.0526$ ).

Seasonality was observed for the total biomass of the assemblage, and maximum values were found in summer (July) and minimum values at the end of win- 


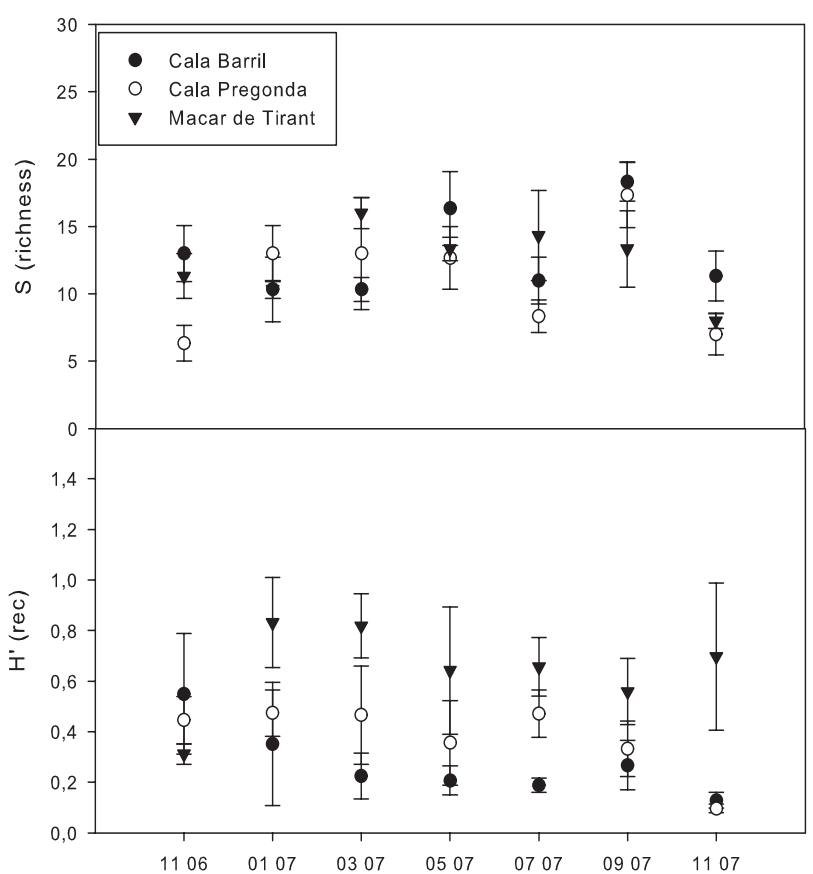

FIG. 5. - Mean richness (number of species per sample) and Shannon diversity $( \pm 1 \mathrm{SE})$ for each sampling time and location. ter (March) (ANOVA, $P<0.05$; see Table 3 and Fig. 4). The biomass of the dominant species $(C$. crinita) was also significantly higher in summer than in winter; and this parameter also differed among locations with significantly higher values in Cala Barril than in Macar de Tirant (ANOVA, $P<0.05$; see Table 3 and Fig. 4). The biomass of companion species differed significantly among locations, with higher values in Macar de Tirant than in Cala Barril, but did not differ among sampling times. ANOVA indicated significant differences in richness (number of species per sample) among sampling times, with maximum values in late summer (September) and minimum values in early winter (November) (Table 3, Fig. 5). No seasonal pattern was found for Shannon diversity, but significant differences were found for this parameter among sampling locations, with significantly higher values in Macar de Tirant than in Cala Pregonda and Cala Barril (Table 3, Fig. 5).

\section{Annual production}

The mean annual branch production of $C$. crinita was $962.1 \mathrm{~g} \mathrm{dwt} \mathrm{m}^{-2}$, and the mean annual cauloid production of C. crinita was $267.6 \mathrm{~g}$ dwt $\mathrm{m}^{-2}$ (Table 4).

TABLE 4. - Annual production of C. crinita branches and cauloids. t: time (days), $\mathrm{B}_{2}$ : biomass $\left(\mathrm{g} \mathrm{dwt} \mathrm{m}^{-2}\right)$ at the end of the period, $\mathrm{B}_{1}$ : biomass at the beginning of the period, $\mathrm{P}$ : production $\left(\mathrm{g} \mathrm{dwt} \mathrm{m}^{-2}\right), \mathrm{r}$ (daily biomass turnover ratio).

\begin{tabular}{|c|c|c|c|c|c|c|}
\hline Location & Period & $\mathrm{t}$ & $\mathrm{B}_{2}$ & $\mathrm{~B}_{1}$ & $\mathrm{P}$ & $\mathrm{r}$ \\
\hline \multicolumn{7}{|l|}{ Branches } \\
\hline \multirow[t]{7}{*}{ Cala Barril } & 14 Oct 06 - 09 Jan 07 & 87 & 663.7 & 899.9 & 0.0 & 0.000 \\
\hline & 10 Jan 07 - 23 Mar 07 & 72 & 774.2 & 663.7 & 110.5 & 0.002 \\
\hline & 24 Mar 07 - 24 May 07 & 61 & 1348.9 & 774.2 & 574.7 & 0.009 \\
\hline & 25 May 07 - 27 Jul 07 & 63 & 1434.9 & 1348.9 & 86.0 & 0.001 \\
\hline & 28 Jul $07-21$ Sep 07 & 55 & 690.4 & 1434.9 & 0.0 & 0.000 \\
\hline & 22 Sep $07-22$ Nov 07 & 61 & 802.5 & 690.4 & 112.0 & 0.002 \\
\hline & Annual production & & & & 883.3 & \\
\hline \multirow{7}{*}{ Cala Pregonda } & 10 Nov 06 - 08 Jan 07 & 59 & 402.6 & 630.7 & 0.0 & 0.000 \\
\hline & 09 Jan 07 - 03 Apr 07 & 84 & 545.9 & 402.6 & 143.4 & 0.004 \\
\hline & 04 Apr 07 - 22 May 07 & 48 & 922.7 & 545.9 & 376.8 & 0.011 \\
\hline & 23 May 07 - 20 Jul 07 & 58 & 1737.5 & 922.7 & 814.8 & 0.011 \\
\hline & $21 \mathrm{Jul} 07$ - $17 \mathrm{Sep} 07$ & 58 & 1155.0 & 1737.5 & 0.0 & 0.000 \\
\hline & 18 Sep $07-20$ Nov 07 & 63 & 713.0 & 1155.0 & 0.0 & 0.000 \\
\hline & Annual production & & & & 1334.9 & \\
\hline \multirow[t]{8}{*}{ Macar de Tirant } & 09 Nov 06 - 13 Jan 07 & 65 & 92.2 & 803.8 & 0.0 & 0.000 \\
\hline & 14 Jan 07 - 04 Apr 07 & 80 & 315.5 & 92.2 & 223.3 & 0.015 \\
\hline & 05 Apr 07 - 23 May 07 & 48 & 497.5 & 315.5 & 182.0 & 0.009 \\
\hline & 24 May 07 - 23 Jul 07 & 60 & 760.4 & 497.5 & 263.0 & 0.007 \\
\hline & 24 Jul $07-18$ Sep 07 & 56 & 512.5 & 760.4 & 0.0 & 0.000 \\
\hline & 19 Sep $07-14$ Nov 07 & 56 & 255.4 & 512.5 & 0.0 & 0.000 \\
\hline & Annual production & & & & 668.3 & \\
\hline & Mean annual branch production & & & & 962.1 & \\
\hline \multicolumn{7}{|l|}{ Cauloids } \\
\hline \multirow[t]{5}{*}{ Cala Pregonda } & 01 May 07 - 01 Sep 07 & & 790.7 & 672.0 & 118.7 & 0.0013 \\
\hline & 02 Sep 07 - 01 Jan 08 & 121 & 885.7 & 790.7 & 95.0 & 0.0009 \\
\hline & 02 Jan 08 - 01 Apr 08 & 90 & 915.5 & 885.7 & 29.8 & 0.0004 \\
\hline & 02 Apr 08 - 02 May 08 & 30 & 939.6 & 915.5 & 24.1 & 0.0008 \\
\hline & Mean annual cauloid production & & & & 267.6 & \\
\hline
\end{tabular}


TABLE 5. - Structural parameters of different Cystoseira-dominated assemblages from the northwestern Mediterranean (A: sampling area in $\mathrm{cm}^{2} ; \mathrm{N}$ : number of species per sample; B: biomass in $\mathrm{g} \mathrm{dwt} \mathrm{m}^{-2} ; \mathrm{P}$ gdwt: annual production of the dominant species in $\mathrm{g} \mathrm{dwt}^{-2} \mathrm{y}^{-1} ; \mathrm{P} \mathrm{g} \mathrm{C}^{-1}$ annual production of the dominant species in $\mathrm{g} \mathrm{C} \mathrm{m}^{-2} \mathrm{y}^{-1}$ ).

\begin{tabular}{lcccccl}
\hline Dominant species & $\mathrm{A}$ & $\mathrm{N}$ & $\mathrm{B}$ & $\mathrm{P}$ gdwt & P gC & Reference \\
\hline Cystoseira crinita & 400 & 13 & 1532.9 & 1230 & $307.5^{\mathrm{a}}$ & this study \\
Cystoseira crinita & 400 & 62 & 2141.7 & 1127 & 304.9 & Ballesteros (1992) \\
Cystoseira crinita & 1600 & 31 & ---- & -- & - & Pizzuto (1999) \\
Cystoseira caespitosa & 784 & 105 & 1438.8 & 630 & 233.9 & Ballesteros (1990a) \\
Cystoseira balearica & 250 & 84 & --- & -- & -- & Verlaque (1987) \\
Cystoseira mediterranea & 784 & 51 & 1698.6 & 2600 & 908.9 & Ballesteros (1988a) \\
Cystoseira stricta & 250 & 36 & --- & --- & -- & Verlaque (1987) \\
Cystoseira zosteroides & 1600 & 132 & 1424.9 & 70 & 24.2 & Ballesteros (1990b) \\
\hline
\end{tabular}

aValue estimated from the production in $\mathrm{g} \mathrm{dwt} \mathrm{m}^{-2}$ multiplied by the factor 0.4 (Ballesteros 1989).

Branch production was highly seasonal with maximum values in spring, and null values in winter and at the end of summer. The daily turnover ratio was highest in late winter and spring.

\section{DISCUSSION}

\section{Seasonal dynamics of assemblage structure}

Although the assemblages dominated by $C$. crinita are highly structured (Molinier 1960, Boudouresque 1972, Ballesteros 1992, Pizzuto 1999), they seem to be less rich in species than assemblages dominated by other Cystoseira species from the NW Mediterranean (Table 5). This could be related to the particular places where these assemblages occur, which are usually exposed to a high degree of sediment abrasion.

A seasonal pattern was found in the structure of the C. crinita-dominated assemblages, mainly related to seasonal variation in $C$. crinita biomass, in close coincidence with seasonal temperature variation (minimum values in March and maximum values in July). Seasonality was also detected in species richness, which had a minimum peak in January, coinciding with minimum values of irradiance, and a maximum peak in September when the water is still warm but $C$. crinita biomass has decreased. Indeed, light intensity and temperature are usually the most important factors determining the seasonal patterns of growth and primary production of seaweeds (Chesire et al. 1996). The seasonal patterns found in this study agree with those described for other phytobenthic Mediterranean assemblages (Ballesteros 1990a), with the maximum biomass in late spring and the maximum species richness in autumn. Compared to C. crinita-dominated assemblages from other areas in the Mediterranean, C. crinita-dominated assemblages from Menorca show reduced seasonality as $C$. crinita plants keep their branches throughout the entire year, similarly to what Pizzuto $(1997,1999)$ found in assemblages from Sicily. In contrast, Sauvageau (1912) and Ballesteros (1992) described almost complete loss of branches in winter for $C$. crinita from Catalonia and the Albères coast (France). Populations from Mallorca (Balearic islands) and Algiers (southern Mediterranean) seem to display a marked seasonality, and cauloids are al- most devoid of branches from April to August, with the highest development of branches at the end of winter (Sauvageau 1912, Gómez et al. 1982). These differences in seasonality may be due to environmental differences already described between the northern Mediterranean and the central and southern Mediterranean areas (e.g. differences in temperature and trophic regime; Sales et al. 2012) or to local environmental conditions.

Although seasonality was found for some structural parameters of the assemblage, location was an even more important factor in determining community structure, as evidenced by the MDS plot. Important variations in local factors, like exposure degree, morphology of the coast and nutrient concentration, could explain this pattern. The C. crinita-dominated assemblages from Cala Pregonda and Cala Barril showed erratic temporal trajectories in the MDS plot, tending to an upper position from November 2006 to November 2007. This pattern closely agrees with the model presented by Ballesteros (1990c), suggesting that the assemblages tend to a different state with multiple intermediate stable points. In contrast, in Macar de Tirant the temporal trajectory described by the assemblages was circular and returned back to the original state after one year. In this location, assemblages were greatly desiccated in January 2007 due to high atmospheric pressure that affected the sea water level at the study locations. This suggests that the assemblage was able to recover from this natural disturbance in just one year.

\section{Annual production}

The annual production of the studied $C$. crinitadominated assemblages was lower than that estimated for assemblages dominated by Cystoseira mediterranea that grow in exposed areas, but considerably higher than that of assemblages dominated by Cystoseira caespitosa (growing in sheltered areas) and assemblages dominated by Cystoseira zosteroides (from deeper areas; Table 5). This pattern is probably due to the influence of hydrodynamism, which usually increases primary production (Leight et al. 1987). Compared to other abundant and well-known Mediterranean macrophytes, such as the seagrasses 
Posidonia oceanica (estimated production of 238-714

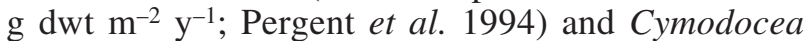
nodosa (usually $160-820 \mathrm{~g} \mathrm{dwt} \mathrm{m}^{-2} \mathrm{y}^{-1}$ but up to 2470 g dwt $\mathrm{m}^{-2} \mathrm{y}^{-1}$; Agostini et al. 2003), or other algae such as Rissoella verruculosa (1241 $\mathrm{g} \mathrm{dwt} \mathrm{m}^{-2} \mathrm{y}^{-1}$; Ballesteros 1991a), Halimeda tuna (680 g dwt $\mathrm{m}^{-2}$ $\mathrm{y}^{-1}$; Ballesteros 1991b) and Codium vermilara (295 g dwt $\mathrm{m}^{-2} \mathrm{y}^{-1}$; Ballesteros 1988b), the primary production values estimated for $C$. crinita-dominated assemblages in this study (1230 g dwt m$\left.{ }^{-2} \mathrm{y}^{-1}\right)$ are amongst the highest. Moreover, it should be considered that the results on annual production presented in this paper are an underestimation, as biomass losses due, for example, to herbivory and storms have not been taken into account (Golléty et al. 2008).

The annual production values estimated for Cystoseira-dominated assemblages are comparable to other marine systems around the world that are considered very productive, as for example kelp beds and seagrasses (Mann 1973 and references therein). However, while the role of Cystoseira in structuring ecosystems is well recognized (e.g. Bulleri et al. 2002), much less attention has been paid to its role in ecosystem carbon budgets. We know of only one study in which Cystoseira balearica is demonstrated to be a source of carbon for species inhabiting adjoining ecosystems (Cardona et al. 2007).

\section{Conclusion}

In conclusion, we found a seasonal pattern for the structural and functional parameters of Cystoseira crinita-dominated assemblages. The seasonality is mainly due to the change in biomass of the dominant species — with minimum values between January and March and maximum values in July —and to the variation in species richness — with minimum values in November and a secondary minimum peak in July, and maximum values in September. Variation in $C$. crinita biomass coincides with seasonal temperature variation, while fluctuations in species richness agree with the seasonal pattern in irradiance combined with a negative effect of $C$. crinita biomass in July. Although the mean annual production values of the assemblages dominated by $C$. crinita are lower than those of assemblages dominated by Cystoseira species growing in exposed zones, they are still comparable to some of the most productive marine systems.

\section{ACKNOWLEDGEMENTS}

MS was funded by a FI grant from Generalitat de Catalunya co-funded by the European Social Fund and by a grant from Institut Menorquí d'Estudis. The authors are grateful to the Direcció General de Pesca of the Balearic Islands Government for giving them permission for working and collecting samples from the study sites, included in the MPA Reserva Marina del Nord de Menorca.

\section{REFERENCES}

Aburto-Oropeza O., Sala E., Paredes G., Mendoza A., Ballesteros E. 2007. Predictability of reef fish recruitment in a highly variable nursery habitat. Ecology 88: 2220-2228.

Agostini S., Pergent G., Marchand B. 2003. Growth and primary production of Cymodocea nodosa in a coastal lagoon Aquat. Bot. 76: 185-193.

Anderson M.J. 2001. A new method for non-parametric multivariate analysis of variance. Aust. Ecol. 26: 32-46.

Anderson M.J., Gorley R.N., Clarke K.R. 2008. Permanova + for Primer: Guide to Software and Statistical Methods. Primer-E Ltd, United Kingdom, 213 pp.

Ballesteros E. 1986. Métodos de análisis estructural en comunidades naturales, en particular del fitobentos. Oecol. Aquat. 8: 117-131.

Ballesteros E. 1988a. Estructura y dinámica de la comunidad de Cystoseira mediterranea Sauvageau en el Mediterráneo Noroccidental. Inv. Pesq. 52: 313-334.

Ballesteros E. 1988b. Estructura y dinámica de la comunidad infralitoral de Codium vermilara (Olivi) Delle Chiaje de la Costa Brava (Mediterráneo Occidental). Anal. Biol. 15: 191-208.

Ballesteros E. 1989. Production of seaweeds in north-western Mediterranean marine communities: its relation with environmental factors. Sci. Mar. 53: 357-364.

Ballesteros E. 1990a. Structure and dynamics of north-western Mediterranean phytobenthic communities: a conceptual model. Oecol. Aquat. 10: 223-242.

Ballesteros E. 1990b. Structure and dynamics of the community of Cystoseira zosteroides (Turner) C. Agardh (Fucales, Phaeophyceae) in the north-western Mediterranean. Sci. Mar. 54: 217-229.

Ballesteros E. 1990c. Structure and dynamics of the Cystoseira caespitosa Sauvageau (Fucales, Phaeophyceae) community in the north-western Mediterranean. Sci. Mar. 54: 155-168.

Ballesteros E. 1991a. Seasonality of growth and production of a deep-water population of Halimeda tuna (Chlorophyceae, Caulerpales) in the North-western Mediterranean. Bot. Mar. 34: 291-301.

Ballesteros E. 1991b. Structure and dynamics of the community of Rissoella verruculosa (Bertoloni) J. Agardh (Gigartinales, Rhodophyceae) in the northwestern Mediterranean. Sci. Mar. 55: 439-451.

Ballesteros E. 1992. Els vegetals $i$ la zonació litoral: espècies, comunitats $i$ factors que influeixen en la seva distribució. Arxius de la Secció de Ciències, 101. Institut d'Estudis Catalans, Barcelona, 613 pp.

Boudouresque C.F. 1971. Méthodes d'étude qualitative et quantitative du benthos (en particulier du phytobenthos). Tethys 3: 79-104.

Boudouresque C.F. 1972. Recherches de bionomie analytique, structurale et expérimentale sur les peuplements benthiques sciaphiles de Méditerranée Occidentale (fraction algale): le sous-strate sciaphile d'un peuplement photophile de mode calme, le peuplement à Cystoseira crinita. Bull. Musée Hist. Nat. Marseille 32: 253-263.

Bray J.R., Curtis J.T. 1957. An ordination of the upland forest communities of southern Wisconsin. Ecol. Monogr. 27: 325-349.

Bulleri F., Benedetti-Cecchi L., Acunto S., Cinelli F., Hawkins S.J. 2002. The influence of canopy algae on vertical patterns of distribution of low-shore assemblages on rocky coasts in the northwest Mediterranean. J. Exp. Mar. Biol. Ecol. 267: 89-106.

Cardona L., Revelles M., Sales M., Aguilar A., Borrell A. 2007. Meadows of the seagrass Posidonia oceanica are a significant source of organic matter for adjoining ecosystems. Mar. Ecol. Progr. Ser. 335: 123-131.

Cheminee A., Sala E., Pastor J., Mangialajo L., Cottalorda J.M., Bodilis P., Bianchimani O., Arceo H., Francour P. 2010. Algal forests and the replenishment of Mediterranean rocky fishes. Consequences of the decline of Cystoseira forests on Mediterranean juvenile fish populations. ICES 2010. ASC Edition, p Q17.

Chesire A.C., Westphalen G., Wenden A., Scriven L.J., Rowland B.C. 1996. Photosynthesis and respiration of phaeophyceandominated macroalgal communities in summer and winter. Aquat. Bot. 55: 159-170.

Clarke K.R., Gorley R.N. 2006. Primer v6: User Manual/Tutorial. 
Primer-E Ltd, United Kingdom, 190 pp.

Coppejans E. 1980. Phytosociological studies on Mediterranean algal vegetation: rocky surfaces of the photophilic infralittoral zone. In: Price J.H., Irvine D.E.G., Farnham W.F. (eds.), The shore environment, vol. 2: Ecosystems. Academic Press, London, pp. 371-393.

Cormaci M., Furnari G. 1999. Changes of the benthic algal flora of the Tremiti Islands (southern Adriatic) Italy. Hydrobiologia 398-399: 75-79.

Dayton P.K. 1985. Ecology of kelp communities. Annu. Rev. Ecol. Syst. 16: 215-245.

Draisma S.G.A., Ballesteros E., Rosseau F., Thibaut T. 2010. DNA sequence data demonstrate the polyphyly of the genus Cystoseira and other Sargassaceae genera (Phaeophyceae). J. Phycol. 46: $1329-1345$.

Duggins D.O. 1980. Kelp beds and sea otters: an experimental approach. Ecology 61: 447-453.

Giaccone G. 1971. Contributo allo studio dei popolamenti algali del basso Tirreno. Ann. Univ. Ferrara 4: 17-43.

Giaccone G. 1973. Écologie et chorologie des Cystoseira de Méditerranée. Rapp. Com. Int. mer Médit. 22: 49-50.

Golléty C., Migné A., Davoult D. 2008. Benthic metabolism on a sheltered rocky shore: role of the canopy in the carbon budget. J. Phycol. 44: 1146-1153.

Gómez A., Ribera M.A., Seoane J.A. 1982. Aportación al estudio fenológico de las algas de la isla de Mallorca. Boll. Soc. Hist. Nat. Balears 26: 37-62.

Graham M.H. 2004. Effects of local deforestation on the diversity and structure of southern California giant kelp forest food webs Ecosystems 7: 341-357.

Grasshoff K., Ehrhardt M., Kremling K. 1983. Methods of seawater analysis. Verlag Chimie, Germany, 192 pp.

Kruskal J.B., Wish M. 1978. Multidimensional scaling. Sage Publications, Beverly Hills, California.

Leight E.G., Paine R.T., Quinn J.F., Suchanek T.M. 1987. Wave energy and intertidal productivity. Proc. Natl. Acad. Sci. USA 84: 1314-1318.

Mangialajo L., Chiantore M., Cattaneo-Vietti R. 2008. Loss of fucoid algae along a gradient of urbanisation, and structure of benthic assemblages. Mar. Ecol. Progr. Ser. 358: 63-74.

Mann K.H. 1973. Seaweeds: their productivity and strategy for growth. Science 182: 975-981.

Molinier R. 1960. Étude des biocenoses marines du Cap Corse. Vegetatio 9: 217-231.

Pergent G., Romero J., Pergent-Martini C., Mateo M.A., Boudouresque C.F. 1994. Primary production, stocks and fluxes in the Mediterranean seagrass Posidonia oceanica. Mar. Ecol. Progr. Ser. 106: 139-146.

Pizzuto F. 1997. Fenologia morfologica e riproduttiva di Cystoseira crinita Duby (Fucales, Fucophyceae) di Isola delle Correnti (Siracusa, Italia). Boll. Accad. Gioenia Sci. Nat. 30: 129-136.

Pizzuto F. 1999. On the structure, typology and periodism of a Cystoseira brachycarpa J. Agardh emend. Giaccone community and of a Cystoseira crinita Duby community from the eastern coast of Sicily (Mediterranean Sea). Plant Biosyst. 133: 15-35.

Reed D.C., Foster M.S. 1984. The effects of canopy shading on algal recruitment and growth in a giant kelp forest. Ecology 65: 937-948.

Ribera M.A., Garreta A.G., Gallardo T., Cormaci M., Furnari G., Giaccone G. 1992. Check-list of Mediterranean Seaweeds. I. Fucophyceae (Warming, 1884). Bot. Mar. 35: 109-130.

Ros J.D., Romero J., Ballesteros E., Gili J.M. 1985. Diving in blue water. The benthos. In: Margalef R. (ed.), Western Mediterranean. Pergamon Press, Oxford, pp. 233-295.

Sales M., Ballesteros E. 2009. Shallow Cystoseira (Fucales: Ochrophyta) assemblages thriving in sheltered areas from Menorca (NW Mediterranean): relationships with environmental factors and anthropogenic pressures. Estuar. Coast. Shelf Sci. 84: 476-482.

Sales M., Ballesteros E. 2010. Long-term comparison of algal assemblages dominated by Cystoseira crinita (Fucales, Heterokontophyta) from Cap Corse (Corsica, North Western Mediterranean). Eur. J. Phycol. 45: 404-412.

Sales M., Cebrian E., Tomas F., Ballesteros E. 2011. Pollution impacts and recovery potential in three species of the genus Cystoseira (Fucales, Heterokontophyta). Estuar., Coast. Shelf Sci. 92: 347-357.

Sales M., Ballesteros E., Anderson M.J., Ivesa L., Cardona E. 2012. Biogeographical patterns of algal communities from the Mediterranean Sea: Cystoseira crinita-dominated assemblages as a case study. J. Biogeogr. 39: 140-152.

Sauvageau C. 1912. À propos des Cystoseira de Banyuls et de Guéthary. Bull. Stat. Biol. Arcachon 14: 133-556.

Serio D., Alongi G., Catra M., Cormaci M., Furnari G. 2006. Changes in the benthic algal flora of Linosa Island (Straits of Sicily, Mediterranean Sea). Bot. Mar. 49: 135-144.

Steneck R.S., Graham M.H., Bourque B.J., Corbett D., Erlandson J.M., Estes J.A., Tegner M.J. 2002. Kelp forest ecosystems: biodiversity, stability, resilience and future. Environ. Conserv. 29: 436-459.

Thibaut T., Pinedo S., Torras X., Ballesteros E. 2005. Long-term decline of the populations of Fucales (Cystoseira spp. and Sargassum spp.) in the Albères coast (France, north-western Mediterranean). Mar. Pollut. Bull. 50: 1472-1489.

Scient. ed.: J. Templado.

Received July 22, 2011. Accepted November 8, 2011.

Published online February 16, 2012. 


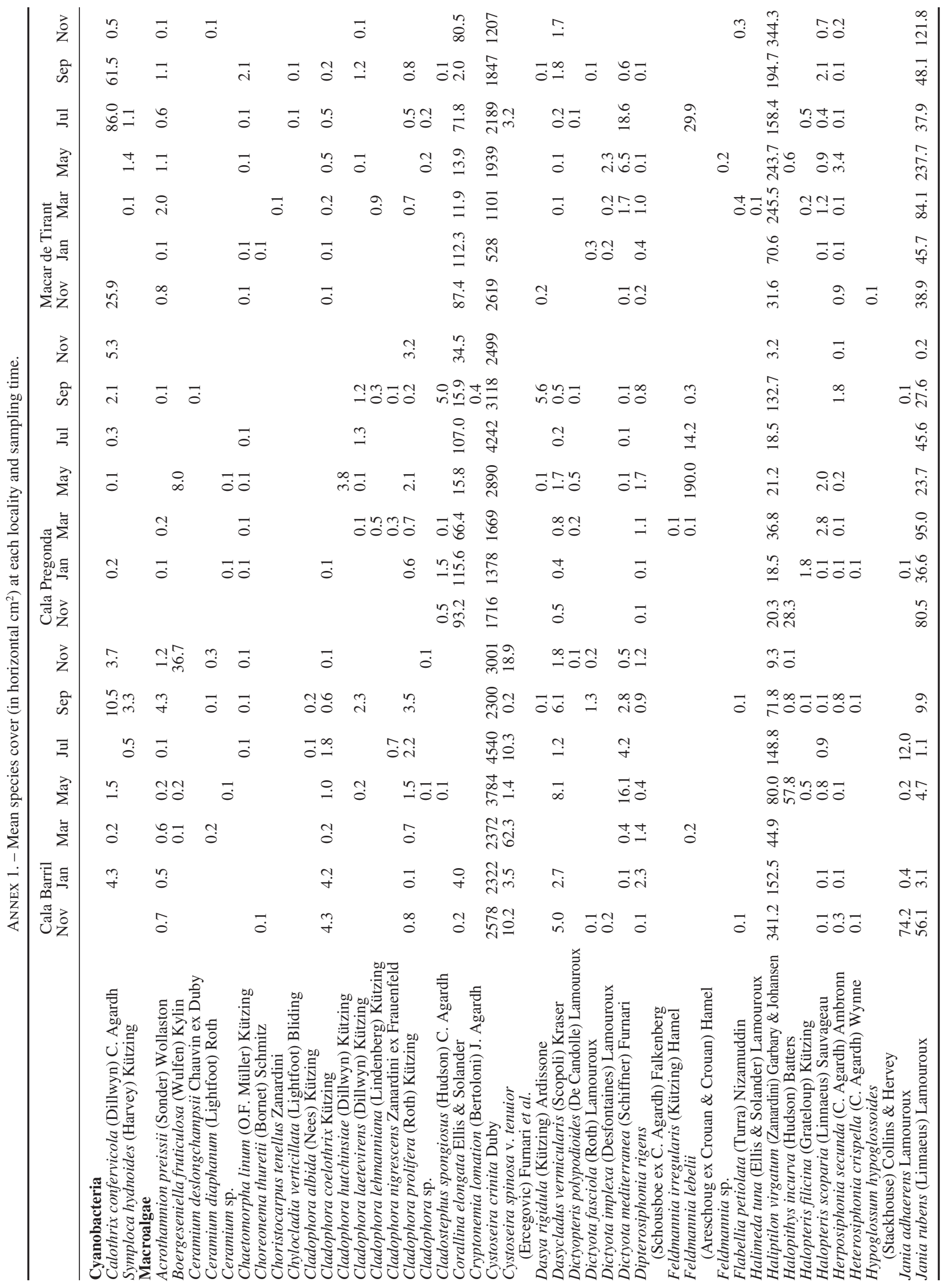

SCI. MAR., 76(2), June 2012, 391-401. ISSN 0214-8358 doi: 10.3989/scimar.03465.16D 


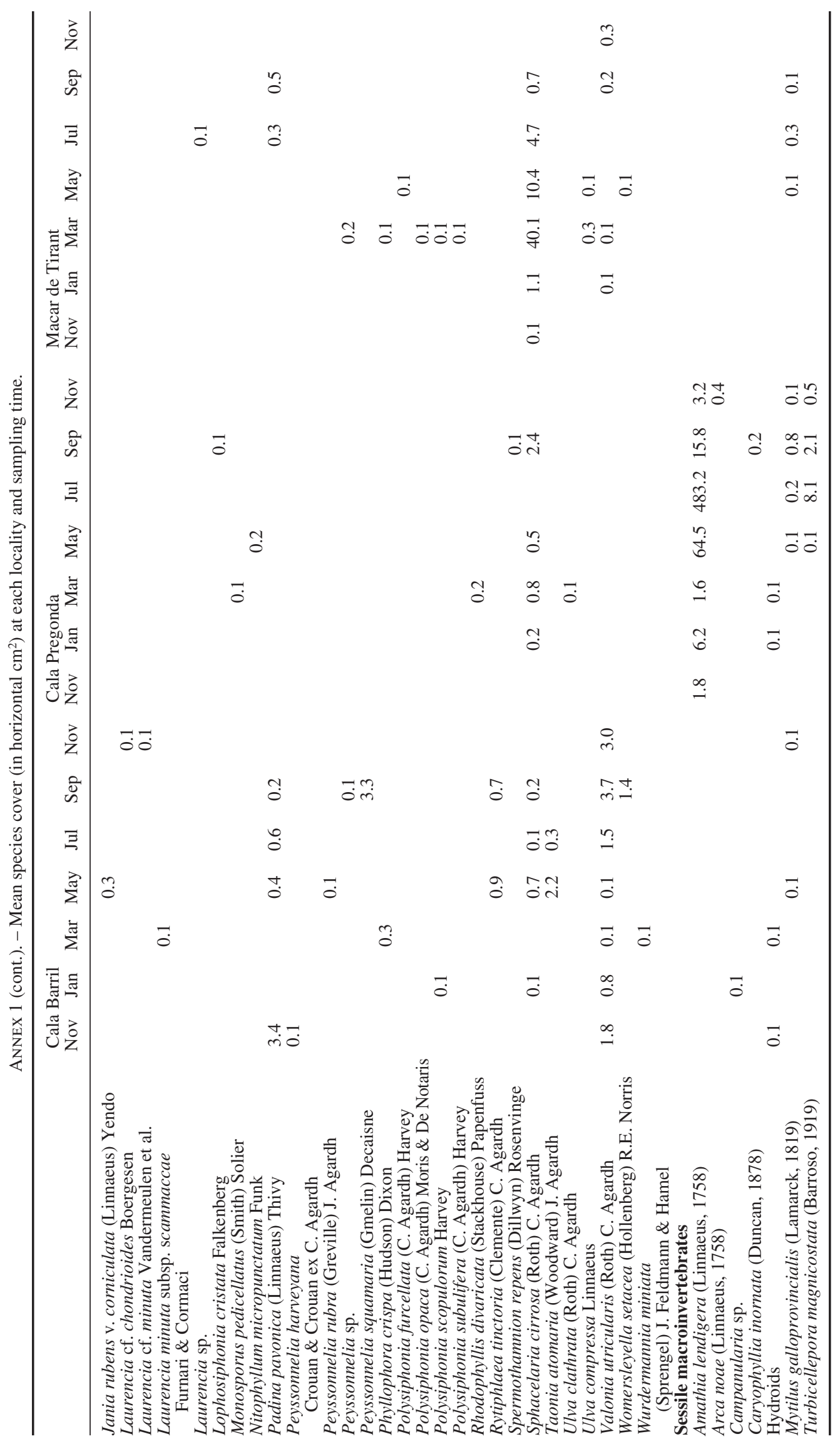

SCI. MAR., 76(2), June 2012, 391-401. ISSN 0214-8358 doi: 10.3989/scimar.03465.16D 